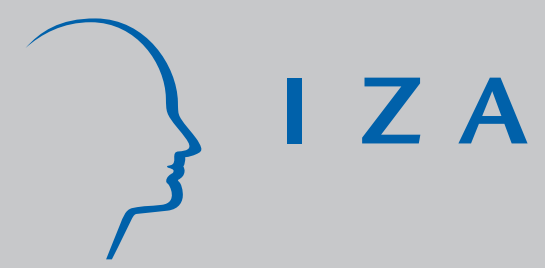

IZA DP No. 7764

Access to Technology and the Transfer Function of Community Colleges:

Evidence from a Field Experiment

Robert W. Fairlie

Samantha H. Grunberg

November 2013 


\title{
Access to Technology and the Transfer Function of Community Colleges: Evidence from a Field Experiment
}

\author{
Robert W. Fairlie \\ University of California, Santa Cruz \\ and IZA \\ Samantha H. Grunberg \\ U.S. Securities and Exchange Commission
}

Discussion Paper No. 7764

November 2013

\author{
IZA \\ P.O. Box 7240 \\ 53072 Bonn \\ Germany \\ Phone: +49-228-3894-0 \\ Fax: +49-228-3894-180 \\ E-mail: iza@iza.org
}

Any opinions expressed here are those of the author(s) and not those of IZA. Research published in this series may include views on policy, but the institute itself takes no institutional policy positions. The IZA research network is committed to the IZA Guiding Principles of Research Integrity.

The Institute for the Study of Labor (IZA) in Bonn is a local and virtual international research center and a place of communication between science, politics and business. IZA is an independent nonprofit organization supported by Deutsche Post Foundation. The center is associated with the University of Bonn and offers a stimulating research environment through its international network, workshops and conferences, data service, project support, research visits and doctoral program. IZA engages in (i) original and internationally competitive research in all fields of labor economics, (ii) development of policy concepts, and (iii) dissemination of research results and concepts to the interested public.

IZA Discussion Papers often represent preliminary work and are circulated to encourage discussion. Citation of such a paper should account for its provisional character. A revised version may be available directly from the author. 


\section{ABSTRACT \\ Access to Technology and the Transfer Function of Community Colleges: Evidence from a Field Experiment ${ }^{*}$}

Access to information may represent an important barrier to learning about and ultimately transferring to 4-year colleges for low-income community college students. This paper explores the role that access to information technology, in particular, plays in enhancing, or possibly detracting from, the transfer function of the community college. Using data from the first-ever field experiment randomly providing free computers to students, we examine the relationships between access to home computers and enrollment in transferable courses and actual transfers to 4-year colleges. The results from the field experiment indicate that the treatment group of students receiving free computers has a 4.5 percentage point higher probability of taking transferable courses than the control group of students not receiving free computers. The evidence is less clear for the effects on actual transfers to 4-year colleges and the probability of using a computer to search for college information (which possibly represents one of the mechanisms for positive effects). In both cases, point estimates are positive, but the confidence intervals are wide. Finally, power calculations indicate that sample sizes would have to be considerably larger to find statistically significant treatment effects and reasonably precise confidence intervals given the actual transfer rate point estimates.

JEL Classification: I21, J24, O33

Keywords: computer, experiment, ICT, community college, transfers, technology

Corresponding author:

Robert W. Fairlie

Department of Economics

University of California, Santa Cruz

1156 High St

Santa Cruz, CA 95064

USA

E-mail: rfairlie@ucsc.edu

\footnotetext{
* We thank the Community Technology Foundation of California (ZeroDivide), UCACCORD, and Computers for Classrooms, Inc. for funding. We thank Julie Cullen, Chris Jepsen, and participants at seminars and workshops at the Center for Human Potential and Public Policy, the University of Chicago, UCLA, University College Dublin, UC Irvine, the University of Wisconsin, San Francisco Federal Reserve, UCSC and APPAM meetings for comments and suggestions on the research project. We also thank Mike Rasmussen, Karen Micalizio, Katalin Miko, Bev McManus, Linda Cobbler, Zeke Rogers and others at Butte College for helping with administering the program and providing administrative data, and Miranda Schirmer, Luba Petersen, Caitlin White, Anita McSwane-Williams, Matt Jennings, Emilie Juncker, and Cody Kennedy for research assistance. Finally, special thanks go to Pat Furr for providing computers for the study and for her extensive help in administering the giveaway program.
} 


\section{Introduction}

Community colleges enroll nearly half of all students attending public universities and an even larger share of low-income and minority students (U.S. Department of Education 2011). ${ }^{1}$ Community colleges are likely to play an increasingly important role in higher education and educating the future high-skilled workforce. Growth in the total number of enrollments in 2-year colleges has outpaced the growth rate for 4-year colleges over the past three decades, and President Obama recently proposed an unprecedented funding increase for community colleges with the goal of boosting the number of graduates by 5 million by 2020 (U.S. White House 2009). One of the primary goals of community colleges is to provide basic requirements training for entry to 4-year colleges. The cost savings from spending two years at a community college before entering a 4-year college can be substantial - average full-time annual tuition at a community college is $\$ 2,439$ compared with $\$ 7,136$ at a public university and $\$ 22,771$ at a private university (U.S. Department of Education 2011). In some states with large community college systems, such as California, nearly half of all students attending a 4-year college previously attended a community college (California Community Colleges Chancellor's Office 2009).

A potential constraint to transferring to 4-year colleges for some students, however, is limited access to information (Furchtgott-Roth, Jacobson, and Mokher 2009, American Association of Community Colleges 2004, Dowd and Gabbard 2006). Acquiring information about 4-year university choices, admission requirements, tuition, financial aid, and which courses are transferable is likely to be greatly enhanced through the use of information technology. ${ }^{2}$ In California for example, the widely-used web page, assist.org, provides detailed school-to-school information on transferable courses, articulation agreements and majors for all community

\footnotetext{
${ }^{1}$ In some states the share is even higher. For example, in California, community colleges enroll more than 70 percent of all students attending public colleges (Sengupta and Jepsen 2006).

${ }^{2}$ A proliferation of web sites, such as collegeboard.com, fastweb.com, and www.fafsa.ed.gov, provide financial aid, application, course, SAT, and other information about 2- and 4-year colleges.
} 
colleges and 4-year universities in the state. ${ }^{3}$ But, 1.2 million community college students do not have access to computers at home with the Internet. ${ }^{4}$ The lack of access to home computers is especially acute among low-income students attending community colleges - roughly one-third of students living in households with less than $\$ 20,000$ in household income do not have computers with Internet access at home (see Figure 1). These disparities reflect broader patterns of disparities in access to home computers, Internet and other technology by income (U.S. Department of Commerce 2008, Fairlie 2004, Goldfarb and Prince 2008, Ono and Zavodny 2003, Warschauer 2003, Mossberger, et al. 2003, 2006, Hoffman and Novak 1998). Unlike 4-year colleges, where many students live on campus and have access to large computer labs, community college students often have limited access to on-campus technology making home access important for acquiring information. Additionally, the increased time and flexibility provided by having access to computers at home may improve the ability of community college students to perform better in college and take more challenging transferable courses. ${ }^{5}$ Therefore, disparities in access to technology might represent an inefficient barrier for low-income students who could otherwise benefit from transferring to 4-year colleges.

On the other hand, having access to a home computer may enhance the ability of community college students to acquire information about the value, requirements and career opportunities provided by 2-year college degrees and certificates. Although the original goal of community colleges was to provide basic requirements training for entry to 4-year colleges, their role in providing terminal degrees, workforce training, and basic skills education has expanded (Leigh and Gill 2007). The labor market returns for the various degrees, diplomas, and

\footnotetext{
${ }^{3}$ All 4-year public institutions in California also provide college admission notifications on password protected web sites (Venegas 2007).

${ }^{4}$ Estimates are derived from microdata from the 2010 Computer and Internet Supplement to the Current Population Survey.

${ }^{5}$ The previous literature provides some evidence of positive effects of home computers on educational outcomes such as test scores, grades and graduation, but overall the evidence is mixed (see Attewell and Battle 1999, Schmitt and Wadsworth 2006, Fuchs and Woessmann 2004, Fairlie 2005, Fairlie, Beltran, and Das 2010, Fairlie and Robinson 2013, Fiorina 2010, Malamud and Pop-Eleches 2010, and Vigdor and Ladd 2010 for example).
} 
certificates offered by community colleges are large (Jepsen et al. 2009). The acquisition of this information may divert students away from transferring to 4-year colleges. A similar concern has been raised about the overall "diversion" effect of community colleges. Several previous studies find that attending a community college lowers the likelihood of ultimately obtaining a bachelor's degree possibly due to increased opportunity costs, inadequate preparation, part-time enrollment, and displacement through curricular emphasis on vocational degrees (Long and Kurlaender 2009, Alfonso 2006). ${ }^{6}$ The increased autonomy offered by access to a home computer may also lead to extensive use for games, networking, downloading music and videos, communicating with friends, and other entertainment, potentially crowding out schoolwork time, college search, and interest in taking more demanding transferable courses (U.S. Department of Commerce 2004, Jones 2002, Lenhart 2009). ${ }^{7}$

Because of these potentially opposing forces, the net effect of having access to a home computer on transferring among community college students is theoretically ambiguous. An empirical test of the hypothesis is therefore needed, but has not been conducted in the previous literature. This is due, in part, to the inherent selection problems in estimating the effects of personal computers on educational outcomes. To address the lack of empirical evidence on the question and concerns about causal inference, we use data from the first-ever field experiment providing free computers to community college students for home use to explore the relationship between access to computers and transferring to 4-year colleges. Participating students were randomly selected to receive free computers and their course taking and transfer behavior was tracked in subsequent years. The random-assignment evaluation is conducted with 286 entering students receiving financial aid at a large community college in Northern California. Previous

\footnotetext{
${ }^{6}$ Previous research, however, also finds evidence that community colleges have increased overall access to higher education often referred to as the "democratization" effect (Leigh and Gill 2003, 2004, Rouse 1995, 1998, Gonzalez and Hilmer 2006).

${ }^{7}$ The impact of the extensive use of Facebook among college students on academic outcomes has recently received some attention (Karpinski 2009 and Pasek and Hargittai 2009). The attention is partly due to the dramatic increase in the use of social networking sites such as Facebook in the past few years (Lenhart 2009). These concerns are similar to those over television (Zavodny 2006).
} 
findings from the experiment provide some evidence that the randomly selected group of students receiving free computers achieved better educational outcomes than the control group that did not receive free computers, but the study does not examine the potential transfer function of the community college (Fairlie and London 2012). ${ }^{8}$

In this paper, we conduct a detailed analysis of the causal effects of home computers on the transfer function of community colleges for low-income students. In an examination of the effects of home computers on several different educational outcomes, Fairlie and London (2012) find positive estimates of the effects on taking transfer courses. We expand on that finding in several ways. First, and foremost, we obtain new data from the National Student Clearinghouse on actual transfers to 4-year colleges among all participants in the experiment. ${ }^{9}$ These data allow for an analysis of not only whether computers affect interest or intent to transfer to a 4-year college, but also whether they affect actual transfers. These data as well as data on transfer course enrollment are taken from administrative data removing concerns about differential attrition or reporting biases. Second, we report new estimates on treatment heterogeneity by educational goals. Focusing on the effects of computers on transfers to 4-year colleges suggests that students with the initial goal of transferring vs. those with another goal might be affected differently. Third, new results on the effects of home computers on self-reported college search are reported. These results provide suggestive evidence on possible mechanisms. The findings on the effects on taking transfer courses, searching for college information, heterogeneity by educational goal, and actual transfer rates are also discussed in the context of the literature examining what contributes to transfer rates among community college students.

\footnotetext{
${ }^{8}$ Previous results from the experiment also indicate that estimates of the effects of home computers on graduating from community college are much smaller than non-experimental estimates from matched CPS data suggesting that non-experimental estimates may be biased upwards (Fairlie and London 2012).

${ }^{9}$ The Institutional Research Department at the community college recently analyzed transfer rates of all of its students through specially commissioned data from the National Student Clearinghouse. We obtained these data for our sample of 286 students participating in the study providing a 4-year window in which to observe transfers.
} 


\section{The Field Experiment}

To examine the effects of home computers on transferring to 4-year colleges, we randomly assigned free computers to entering community college students who were receiving financial aid. The students attended Butte College, which is located in Northern California and has a total enrollment of over 20,000 students. Compared with the average community college in the United States, Butte College is larger, but does not differ substantially in the composition of its student body. For example, Butte College has a roughly similar share of female students as the U.S. total (55.0 percent compared with 58.5 percent) and roughly similar share of nonminority students (65.4 percent compared with 60.8 percent).

To implement the field experiment, letters advertising the computer giveaway program were sent to all financial aid students with less than 24 units attending the college in fall 2006 (see Fairlie and London 2012 for more details on the field experiment). In fall 2006, there were 1,042 financial aid students and 6,681 students in total who met the course unit restriction. Participating students were required to return a baseline questionnaire and consent form releasing future academic records from the college for the study. Students who already owned computers were not excluded from participating in the lottery because their computers may have been much older and not fully functional with the latest software and hardware. ${ }^{10}$ There were 286 students who participated in the study with 141 of these students receiving free computers. All of the computers were refurbished and were provided by Computers for Classrooms, Inc., a computer refurbisher located in Chico, California. ${ }^{11}$ Internet service was not provided as part of the experiment, but we found at the end of the study that more than 90 percent of the treatment group had Internet service. Because of high rates of Internet subscription among computer owners we

\footnotetext{
${ }^{10}$ Twenty-eight percent of students reported already owning a computer. The results presented below are not sensitive to the exclusion of these students.

${ }^{11}$ The computers were refurbished Pentium III 450 MHz machines with 256 MB RAM, 10 GB hard drives, 17" monitors, modems, ethernet cards, CD drives, and Windows 2000 Pro Open Office (with Word, Excel and PowerPoint). Computers for Classrooms offered to replace any computer not functioning properly during the 2-year study period.
} 
cannot identify separate effects of computers and the Internet, which has been a problem in previous studies (Fairlie, Beltan, and Das 2009). More than 90 percent of eligible students picked up their free computers by the end of November 2006.

\section{Who applied for the computer lottery?}

Table 1 reports administrative data from the original application to the college for students applying to the computer-giveaway program, all financial aid students, and all entering students. ${ }^{12}$ The racial composition of study participants is very similar to that of all financial aid students, the group initially targeted for the study. A total of 60.1 percent of study participants are white compared to 61.3 percent of all financial aid students. The largest minority group, Latinos, comprise 16.8 percent of study participants and 15.6 percent of all financial aid students. A similar percentage of primarily English language students also participated in the study compared to all financial aid students. The one difference between study participants and the population of financial aid students is that a larger percentage of women applied for the computer lottery than men. Women comprise 62.6 percent of all study participants which is higher than the 54.7 percent for all financial aid students.

A comparison to all students reveals that study participants are more likely to be female than the total student body. Women comprise 55.2 percent of all students attending the college. Study participants as well as all financial aid students are more likely to be from minority groups than all students, but are less likely to be non-primary English language students, which may be related to applying for financial aid. These differences, however, are small.

Although study participants are a self-selected group from all financial aid students, they do not appear to be very different from either financial aid students or the entire student body along observable characteristics. They may differ, however, along dimensions directly related to participation in the study. Specifically, they may have less access to computers and disposable

\footnotetext{
${ }^{12}$ Baseline and follow-up survey data is only available for study participants.
} 
income than other financial aid students. These differences have implications for our ability to generalize the results based on study participants to all community college students receiving financial aid. But, students with limited access to computers and financial resources are the population of most interest for any policy intervention involving the provision of free or subsidized computers.

\section{Comparability of Treatment and Control Groups}

Table 2 reports a comparison of background characteristics for the treatment and control groups. All study participants were given a baseline survey that included detailed questions on gender, race, age, high school grades, household income, parents' education, and other characteristics. The average age of study participants is 25 . More than half of the students have a parent with at least some college education, and about one third of students received mostly grades of As and Bs in high school. A little over one quarter of study participants have children and one third live with their parents. As would be expected among financial aid students, study participants have low income levels with only 17 percent having current household incomes of $\$ 40,000$ or more. The majority of study participants have household incomes below $\$ 20,000$ and more than half are employed.

The similarity of the mean values of these baseline characteristics confirms that randomization created comparable treatment and control groups for the experiment. We do not find large differences for any of the characteristics, and none of the differences are statistically significant.

\section{Educational Goals at Time of Application}

Butte College provided us with administrative data on the educational goals of all students as reported on their original application to the college. Table 3 reports the distribution of educational goals for all study participants, the treatment and control groups, all financial aid 
students, and all entering students. For all study participants, the most common response is "undecided on goal," which represents 37.4 percent of study participants. The next most common goal reported by applicants is to transfer to a 4-year institution, with 31.5 percent of study participants reporting this goal. Roughly one-fourth of study participants reported a goal other than transferring to a 4-year college. ${ }^{13}$ Due to randomization, the treatment and control groups do not differ in their educational goals as reported on their admission applications. In comparison to all financial aid students, study participants are very similar in their educational goals. In comparison to all entering students, study participants are less likely to report having a transfer goal and are more likely to report having a non-transfer goal, but the overall patterns are roughly similar. These patterns are also generally consistent with those found for the entire California Community College System (Sengupta and Jepsen 2006). We control for educational goals in estimating treatment effects and explore differential treatment effects by educational goal below.

\section{Data on Transfer Courses and Transfer Rates}

Following previous research, we use the course taking behavior of students as a measure of the interest and likelihood of transferring to 4-year colleges (Sengupta and Jepsen 2006, California Community Colleges Chancellor's Office 2009). From an analysis of a special cohort of entering students for the 1997-98 school year linked through system-wide administrative data, Sengupta and Jepsen (2006) find that enrollment in transferable courses in the first and second years of study is a major predictor of who eventually transfers. Butte College provided us with administrative data on all courses taken by study participants over a 2-year period starting at the beginning of the experiment. All of the courses taken by students can be identified as being transferable to the California State University (CSU) or University of California (UC) systems.

\footnotetext{
${ }^{13}$ These goals include obtaining an associate's degree, vocational degree, or vocational certificate without transferring, and discovering career interests, preparing for a new career, updating job skills, maintaining occupational certificates or licenses, intellectual or cultural development, improving basic skills in English, reading, or math, and completing credits for a high school diploma or GED.
} 
For all courses offered at Butte College, 71 percent are transferable to CSU or UC campuses. Transferable courses are spread across a large number of different departments with 86 percent of departments offering at least one transferable course. The number of transferable courses offered by the college and in each department is reported in Appendix Table 1.

Transferable courses can be higher-level courses even though they satisfy lower division credit. In Mathematics, for example, Intermediate Algebra is not transferable and Analytic Geometry/Calculus I is transferable to CSU and UC campuses. Of all courses taken by participants in the experiment 63 percent are transferable to CSU or UC systems.

We also examine actual transfer rates of students participating in the study. For a special study of transfer rates to 4-year colleges, the Institutional Research Department at Butte College purchased data tracking college enrollment activity from the National Student Clearinghouse. Data tracking college enrollment activity through summer 2010 were purchased for every student attending Butte College over the previous several years. We recently found out about the project, and the Institutional Research Department provided us with the data from this special run for all students participating in our random experiment. The system tracks attendance at most colleges in the United States and includes information from CSU and UC campuses. This source is essential because community colleges do not collect (and have no easy way of collecting) information themselves on which students leave and ultimately transfer to 4-year universities. Using these data we find that 21.6 percent of study participants transfer to a 4-year college in the 4-year window. Most of the transferring students transfer to CSU campuses (89.9 percent). Of these students transferring to CSU campuses, most transfer to California State University Chico (75.9 percent). No study participants transfer to University of California campuses.

\section{The Role of Community College as a Gateway to 4-Year Colleges}

Before turning to the results from the experiment, we examine how the California Community College System provides a transfer function to 4-year universities. Butte College is 
part of the California Community College system, which is the largest higher educational system in the nation. The system includes 112 colleges and educates 2.6 million students per year (California Community Colleges Chancellor's Office 2012). As stated in the Master Plan for Higher Education in California, the primary mission of community colleges is to provide academic and vocational instruction through the first two years of undergraduate education (University of California Office of the President 2009). The Plan specifically calls for community colleges to play an important role in admission to the state's 4-year universities. Eligible students transferring from community colleges are given priority in the admissions process at California State University (CSU) and University of California (UC) campuses, and CSU and UC campuses are required to establish a specified lower division to upper division ratio to facilitate transfers.

Agreements between California community colleges and CSU or UC campuses often make it easier for students to transfer as long as they meet specific criteria about taking courses and obtaining grade thresholds. The most common 4-year college that Butte College students transfer to is CSU Chico, which is the closest CSU campus. The eligibility requirements for an upper division transfer to CSU Chico are that students have at least 60 semester (or 90 quarter) transferable units, with 30 semester units of general education. The student must receive a grade of $\mathrm{C}$ or higher in the GE courses, and have a 2.0 or higher overall GPA. Transfers to CSU Chico from community colleges that are outside of their local admission area often face higher GPA requirements. Community college students can also apply to a 4-year college at an earlier stage (referred to as a lower division transfer), but these students have a lower priority in admissions than the upper division transfer applicants.

Attending a community college before attending a 4-year university may be especially attractive to low-income students. The tuition savings from attending two years at a community 
college are substantial. At the national level, average annual tuition at community colleges is $\$ 2,439$ compared with $\$ 7,136$ for public universities and $\$ 22,771$ for private universities (U.S. Department of Education 2011). In California, the cost at community colleges is \$36 per unit or \$864 per year for a full-time student (California Community Colleges Chancellor’s Office 2011). The average annual costs of full-time tuition at a CSU campus are $\$ 6,489$ and $\$ 13,200$ at a UC campus and have been rising rapidly (California Colleges.edu 2012). ${ }^{14}$ In addition to the substantial savings on the cost of education, attending a community college may allow students to improve their academic record and ultimately attend a higher-quality 4-year college (Hilmer 1997).

The number of community college students transferring to 4-year colleges in California has increased steadily over the past several years (California Community Colleges Chancellor's Office 2009). In 2007-08, 105,957 students transferred to 4-year colleges, which represents a 16 percent increase from 2002-03 (see Figure 2). Among all entering California community college students, roughly 15 percent transfer to a 4-year institution within seven years (Sengupta and Jepsen 2006). Transfer rates increase to 26 percent when focusing on community college students who take primarily transfer-eligible courses in their first year and 38 percent for students taking primarily transfer-eligible courses in both their first and second years.

From the perspective of the UC and CSU systems, a strikingly large percentage of students first attended a community college in California (California Community Colleges Chancellor's Office 2009). In the CSU system, 55.3 percent of students from the 2007-08 cohort previously attended a community college. Of the 42,416 students in the 2007-08 cohort in the University of California system, 29.4 percent previously attended a community college. The community college system clearly provides a route to university education for many students in California. Identifying the potential barriers to transferring to 4-year colleges for other students is

\footnotetext{
${ }^{14}$ Average annual tuition was $\$ 8,062$ at UC campuses and \$3,797 at CSU campuses in 2008-2009 (California Teachers Association 2012).
} 
important for improving overall access to higher education. Informational constraints may represent one such barrier to attending 4-year colleges, especially among low-income students (Furchtgott-Roth, Jacobson, and Mokher 2009, American Association of Community Colleges 2004, Dowd and Gabbard 2006).

\section{Home Computer Impacts}

The impact of home computers on students deciding to transfer is ambiguous. Home computers may provide an important tool for finding information about 4-year colleges and help students take challenging transferable courses and ultimately transfer to 4-year colleges. For example, students with home computers and access to the Internet would have more flexibility to explore websites such as, “assist.org,” which allows California community college students to enter their current college and 4-year college of interest and obtain detailed information on which courses are transferrable, different majors, general requirements to earn a degree in that major, and links to other college-related websites. However, computers also allow students to gather more information on the value and requirements of getting an associates or vocational degree, which may discourage students from transferring to 4-year colleges, as well as provide a distraction through their entertainment value. In this section we turn to the field experiment to estimate the transfer function of home computers. We first examine impacts on the likelihood that community college students take courses that are transferable to the CSU or UC systems before turning to an analysis of data on actual transfers. Enrollment in transfer courses proxies for potential interest in transferring which is an important outcome in addition to actual transfers.

Among study participants, 63 percent of all courses taken over the study period are transferable. Of all courses taken by the treatment group, 66 percent are transferable to a CSU or UC campus compared with 61 percent of courses taken by the control group. Table 4 reports estimates of the treatment-control difference from regressions for which there is an indicator 
variable for whether a course is transferable to a CSU or UC campus. The regression equation is straightforward in the context of the field experiment:

(4.1) $\mathrm{y}_{\mathrm{ij}}=\alpha+\beta \mathrm{X}_{\mathrm{i}}+\delta \mathrm{T}_{\mathrm{i}}+\lambda_{\mathrm{t}}+\mathrm{u}_{\mathrm{i}}+\varepsilon_{\mathrm{ij}}$,

where $y_{i j}$ is whether the course is transferable to a CSU or UC campus for student $i$ in course $j, X_{i}$ includes baseline characteristics, $T_{i}$ is the treatment indicator, $\lambda_{t}$ are quarter fixed effects, and $u_{i}+$ $\varepsilon_{\mathrm{ij}}$ is the composite error term. The effect of winning a free computer or the "intent-to-treat" estimate of the giveaway program is captured by $\delta$. All specifications are estimated using OLS and robust standard errors are reported with adjustments for multiple observations per student (i.e. clustered by student). Marginal effects estimates are similar from probit and logit models, and are thus not reported.

Specification 1 reports estimates of the treatment effect without any controls. The point estimate for $\delta$ implies that the treatment group of students receiving free computers has a 4.8 percentage point higher likelihood of taking transfer courses than the control group not receiving free computers. ${ }^{15}$ The treatment-control difference of 4.8 percentage points is statistically significant and represents roughly 8 percent of the control group mean. The 95\% confidence interval for this estimate is 0.001 to 0.095 . Including detailed controls for gender, race/ethnicity, age, parents' highest education level, high school grades, presence of own children, live with parents, family income, and educational goals does not change the result (Specification 2). ${ }^{16}$ These control variables are taken from the baseline survey administered to all study participants before receiving free computers. We continue to find a positive difference between the treatment and control groups. With the controls, the confidence interval is slightly smaller at 0.0002 to

\footnotetext{
${ }^{15}$ We do not find evidence of a trend over the two academic years. The levels and treatment/control difference are very similar in each quarter.

${ }^{16}$ Fairlie and London (2102) report a larger positive estimate which is also statistically significant. The sample used in that study only includes non-recreational courses, which were used in the estimation of the other educational outcomes (e.g. course pass rate) to maintain a consistent sample size. Thus, these estimates are not sensitive to the inclusion or exclusion of recreational courses.
} 
0.0888. Although the point estimates are statistically significant, the confidence intervals just rule out zero.

These estimates are not sensitive to alternative methods of measuring transfer course enrollment. First, we estimate specifications in which the dependent variable measures the percentage of courses taken that are transferable by students. In this case, each student contributes only one observation to the sample. Estimates are reported in Table 5. We find a difference between the treatment and control groups of 5.4 percentage points, which holds with or without controls.

We also estimate regressions for a dummy variable indicating whether the majority of courses taken by students are transferable, following the approach of Sengupta and Jepsen (2006). We find a difference of 7.1 percentage points between the treatment and control groups. Including the full set of controls, we find a very similar estimate for the treatment effect.

We focus on the probability that a course taken is a transferable course in the regressions above (conditioning on taking the course). We also estimate regressions for the total number of courses of any type taken over the sample period and the probability of being enrolled in each quarter. In both cases, we find no evidence of treatment effects. Thus, the computers appear to have affected the types of courses taken (i.e. transfer vs. non-transfer), but not the total number of courses or enrollment at the college. ${ }^{17}$

\section{Adjusting for Non-Compliance}

The estimates presented thus far capture the "intent-to-treat"(ITT) from the experiment and do not adjust for noncompliance in the treatment and control groups. Some of the students in the treatment group did not pick up their free computers, and some of the students in the control group purchased their own computers during the study period. Although the intent-to-treat

\footnotetext{
${ }^{17}$ Given these results, we find that mechanically the treatment group takes more transferable courses than the control group.
} 
estimate is often a parameter of interest in evaluating policies to address the consequences of disparities in access to technology, the "treatment-on-the-treated,"(TOT) or more general, local average treatment effect (LATE) estimates are also of interest. They provide estimates of the effects of having a home computer on the probability of taking transfer courses.

Of the 141 students in the study that were eligible to receive a free computer, 129 students (or 92 percent) actually picked them up from Computers for Classrooms. To adjust for this non-compliance by the treatment group and obtain the TOT estimate, an instrumental variables (IV) regression is estimated. Computer eligibility (winning a free computer) is used as an instrumental variable for whether the student picked up the free computer. The first-stage regression for the probability of computer receipt is:

(4.2) $\mathrm{C}_{\mathrm{i}}=\omega+\gamma \mathrm{X}_{\mathrm{i}}+\pi \mathrm{T}_{\mathrm{i}}+\lambda_{\mathrm{t}}+\mathrm{u}_{\mathrm{i}}+\varepsilon_{\mathrm{ij}}$.

The second-stage regression is:

(4.3) $\mathrm{y}_{\mathrm{ij}}=\alpha_{2}+\beta_{2} \mathrm{X}_{\mathrm{i}}+\Delta \hat{\mathrm{C}}_{\mathrm{i}}+\lambda_{\mathrm{t}}+\mathrm{u}_{\mathrm{i}}+\varepsilon_{\mathrm{ij}}$,

where $\hat{\mathrm{C}}_{\mathrm{i}}$ is the predicted value of computer ownership from (4.2). In this case, $\Delta$ provides an estimate of the "treatment-on-the-treated" effect. The IV estimates for the transfer course rate are reported in Specification 3 of Table 4. Given the high compliance rate for students in the treatment group, the estimates are only slightly larger than the intent-to-treat estimate and approximate the simple OLS coefficient divided by the pick-up rate of 92 percent.

The control group cannot be prevented from purchasing a computer on their own during the study period. This problem of the control group receiving an intervention that potentially has the same effect as the treatment intervention is a similar problem in most social experiments. Results from the follow-up survey taken at the end of the study period indicate that 28 percent of the control group reports getting a new computer, although no information is available on when they purchased the computer. The more general local average treatment effect (LATE) estimator is used to expand on the "treatment-on-the treated" estimates. Specification 3 can be thought of as implicitly assuming that all students in the control group received their computers at the end of 
the study period. In Specification 4 we instead assume that all of the students in the control group reporting obtaining a computer in the follow-up survey received that computer at the beginning of the study period. This new "upper bound" estimate of the LATE is 6.3 percentage points. Given this range of IV estimates, the LATE estimate is between 0.049 and 0.063 , which represents 8 to 10 percent of the mean level of taking transferable courses. The $95 \%$ confidence intervals for these estimates range from just above zero to 0.099 to 0.125 . We continue to report the LATE estimates in all tables, but focus the discussion below on the ITT estimates.

\section{Impacts on Transfers to 4-year Colleges}

We now turn to estimating the effects of home computers on actual transfers to 4-year colleges. Although home computers increase the likelihood of taking transferable courses they might have a different effect on actual transfers to 4-year colleges in which students face additional constraints. Constraints may include the high cost, reduced flexibility in course offerings to accommodate working, and more challenging coursework of 4-year universities (Council on Postsecondary Education 2004). As noted above, information on transfers to 4-year colleges is obtained from college enrollment data from the beginning of the experiment through four years later. We find that 21.3 percent of the treatment group transfers to a 4-year college compared with 20.0 percent of the control group. The difference of 1.3 percentage points, however, is not statistically significant. Table 6 reports estimates of treatment effects using (4.1) for the transfer rate to 4-year colleges. After controlling for baseline characteristics, we find a similar point estimate for the treatment effect, but the coefficient is also statistically insignificant.

Some caution is warranted in interpreting these estimates, however, as the $95 \%$ confidence intervals are very large. With the full set of controls, the confidence interval is -0.081 to 0.101 . Relative to the base transfer rate, this confidence interval ranges from -40 percent of the control group mean to +51 percent of the control group mean implying that only very large negative and positive treatment effects can be ruled out from the experiment. The top end of this 
confidence interval implies extremely large effects: an investment of \$400-500 for a computer would raise the probability that a community college student transfers to 4-year colleges by one half.

With these concerns in mind, the magnitudes implied by the point estimates for the actual transfer rates are smaller than the magnitudes implied by the point estimates for taking transferable courses. The coefficient estimates of 0.0103 (with controls) and 0.0128 (without controls) for the transfer rate represent 5.1 to 6.4 percent of the control group mean. These point estimates are smaller relative to the control group mean than for the point estimates on taking transfer courses. The point estimates for the treatment effect on taking transfer courses represent 7.3 percent (with controls) and 7.8 percent (without controls) of the control group mean. We might expect home computers to have a larger effect on influencing interest in transferring and taking transfer courses than on actual transfers. For actual transfers there are likely to be many additional constraints, especially the inability to pay for higher 4-year college tuition costs. The estimates are not precise enough, however, to reach a definitive conclusion on this issue.

Focusing on transfers to public universities in California, we also estimate specifications in which the dependent variable is whether the student transfers to a CSU campus. Transfers to CSU campuses capture 90 percent of all transfers to 4-year colleges among study participants. Indeed, one of the primary goals of the California community college system is to encourage students to transfer to CSU campuses. Additionally, there are no transfers to the University of California system in the data and some of the transfers to other 4-year colleges are to religious or other specialized colleges, which could be influenced by different factors than transfers to the California State College system. We find that 19.9 percent of the treatment group transfers to a CSU campus compared with 17.1 percent of the control group. Table 7 reports estimates of treatment effect estimates for the CSU system. We find larger, positive point estimates, but the 
estimates remain statistically insignificant. ${ }^{18}$ The confidence intervals also remain relatively large, ranging from -0.060 to 0.115 for the specification with all of the controls.

\section{Power Calculations for Actual Transfer Estimates}

It is useful to consider how large of a sample size would be needed to estimate economically meaningful estimates for the actual transfer rate. Power calculations are relatively simple when comparing two proportions because the variance of the treatment and control means are determined by the base proportion along with the sample size (i.e. no assumptions about the variance of the two means are needed). From the experiment, the control group mean for the actual transfer rate is 0.20 , and the point estimates indicate treatment effect sizes of roughly 0.010 to 0.013 . Appendix Table 2 reports power calculations assuming different effect sizes. ${ }^{19}$ To detect a statistically significant effect for a treatment-control difference of 0.01 at the $\alpha=0.05$ level of significance it would require a sample size of more than 25,000 observations. Given the cost of computers at $\$ 400-500$ conducting an experiment with this many participants would clearly be prohibitively expensive. $^{20}$ To detect a treatment-control difference of 0.02 , which is 10 percent of the control group mean, the sample size would have to be 6,510 observations. The effect size would have to be 0.10 (or 50 percent of the control group mean) to be statistically detectable with sample sizes in the range of what is available in this experiment.

How do we translate these hypothetical treatment effects sizes into whether they are economically meaningful, and thus whether we can detect economically meaningful treatment effects with different sample sizes? One way is to place them in the perspective of reducing disparities in transfer rates. For example, the state-wide difference in transfer rates between underrepresented minorities and whites is roughly 10 percentage points (Sengupta and Jepsen

\footnotetext{
${ }^{18}$ Consistent with this finding, we find negative point treatment estimates (but very imprecise) for the probability of transfers to other 4-year colleges (i.e. not a CSU campus).

${ }^{19}$ Power calculations can be performed in STATA using sampsi or SAS using proc power.

${ }^{20}$ Non-proportion outcome measures that have high variances require especially large sample sizes to reach statistical significance (see Lewis and Reiley 2011 for an example).
} 
2006) suggesting that a policy intervention that could reduce this racial gap by one-fifth (a 0.02 treatment effect) would be economically meaningful. Another method of assessing the magnitude is to examine the total cost of influencing one more student to transfer and comparing it to the potential returns to transferring. A treatment effect of 0.02 which is 10 percent of the control group mean implies that 50 computers (at a total cost of roughly $\$ 22,500$ ) would have to be given out to increase the number of students transferring by 1 . A total cost of $\$ 45,000$ would be required to induce one more transfer with a treatment effect of 0.01 (5 percent of the control group mean). Census Bureau (2011) estimates indicate that mean annual earnings for individuals with a Bachelor's degree are nearly $\$ 25,000$ higher than with an Associate's degree. However, the actual average returns to transferring are likely to be much lower with the uncertainty of obtaining a degree. If these returns were only $\$ 5,000$ per year then the total cost of the computers would be recovered in a few years if the treatment effect is 0.02 , but would take much longer for an effect size of 0.01 . Although it is difficult to determine what an economically meaningful effect size would be in this context, it appears as though an effect size of 0.02 is clearly large, economically meaningful and policy relevant, but even in this case we would need 6,510 observations to obtain statistical significance.

For convenience, Appendix Table 2 also presents information from power calculations in terms of the confidence intervals generated by the sample size of the experiment $(\mathrm{N}=286)$ and a much larger sample size $(\mathrm{N}=5000)$ for the same set of possible treatment effects. With the sample size used in the experiment the confidence intervals on all of the effect sizes are large, often around 10 percentage points or 50 percent of the control group mean on either side of the estimate. Even in the case of the larger sample size with 5,000 observations, which would represent a very expensive experiment, the sample size is not large enough to detect a 0.01 or 0.02 treatment effect. The confidence intervals, however, would be slightly more than 2 percentage points on either side of the estimate (or 10 percent of the control group mean). These 
power calculations demonstrate how difficult it is to find a statistically significant treatment effect or obtain relatively tight confidence intervals for an expensive per-participant experiment.

\section{Treatment Heterogeneity by Educational Goal}

The focus thus far has been on estimating the average treatment effect for all study participants. The literature on the transfer function of community colleges, however, has emphasized the importance of controlling for the educational goals of community college students (see Leigh and Gill 2003, 2007, Alfonso 2006, and Long and Kurlaender 2009 for example). Students attend community colleges for many different reasons potentially placing them at varying levels of risk of having a desire to take transfer courses and transfer to 4-year colleges. As reported in Table 3 and discussed above, we find from administrative data based on the self-reported educational goals of students on their original application to the college, 37.4 percent of study participants reported being "undecided," 31.5 percent reported "transfer to a 4year institution," and 24.5 percent reported a goal other than transferring to a 4-year college. Controlling for these educational goals has little effect on the treatment effect estimates, but there is the possibility that having a home computer may have differential effects on transfer behavior depending on the initial goals of the student.

Table 8 provides evidence on this question from regressions in which treatment status is interacted with the three major educational goals at the time of application. The main treatment effect captures the treatment effect for the most common educational goal, "undecided." For taking transfer courses, we find that home computers have essentially no effect on "undecided" students. The effects of home computers on taking transfer courses are stronger, however, for students with an initial goal of transferring to a 4-year college. We also find that students with non-transfer goals are relatively more likely to take transferable courses when receiving a free computer. The computer may have changed their goal or simply allowed these students to take more challenging and demanding courses at the community college. 
We also explore heterogeneity in treatment effects on transfers to 4-year colleges by initial educational goal. Specification 3 of Table 8 reports these estimates. The results are less clear. We find a positive point estimate on the treatment interaction with having a transfer goal, but the coefficient is small and insignificant. We also find a large negative point estimate on the treatment interaction with having a non-transfer goal, but the coefficient is not significant at conventional levels (t-stat=1.31). Although we should interpret this coefficient with some caution, it suggests the possibility that home computers facilitated these students in taking more advanced transfer courses, but did not ultimately increase their likelihood of transferring to a 4year college.

Instead of using educational goals self-reported by students at the time of application as a measure of transfer goals, we can use pre-treatment transfer course-taking behavior in fall 2006 . $^{21}$ Fall 2006 is generally the first year of courses taken for study participants, and course choices for this term were made prior to when the computers were distributed, which was in October and November 2006. We create a variable that measures the percentage of courses taken in fall 2006 that are transferable for each student. The average value for this variable is 60.5 percent for the control group and 61.4 percent for the treatment group. The difference of 0.9 percent is small and not statistically significant. We interact a dummy variable indicating whether the student had a fall 2006 transfer course percentage higher than the median (0.67) and treatment status, and include it in the regressions reported in Specifications 2 and 4 of Table 8. For the transfer course regression we find a positive main effect of computers, but find a small negative and insignificant coefficient on treatment interacted with taking a large percentage of transfer courses prior to treatment. In the actual transfer regression, we find a small negative coefficient on the main treatment effect and a large positive coefficient on the treatment effect interacted with taking a large percentage of transfer courses in fall 2006. Although the interaction coefficients are not

\footnotetext{
${ }^{21}$ Sengupta and Jepsen (2006) argue that first-year course taking represents a more reliable measure of transfer goals than responses on the application form.
} 
precisely measured, they line up with the findings for treatment interactions with the educational goals students reported at the time of application to the college.

Overall, we find some suggestive evidence indicating that home computers might have helped community college students with the goal of transferring more in taking transfer courses and ultimately transferring to a 4-year college. ${ }^{22}$ For community college students who did not have the goal of transferring, home computers may have encouraged them to take more challenging and demanding transfer courses, but had no differential effect on actual transfers. Unfortunately, we cannot draw strong conclusions from any of these results because of the general lack of precision of estimates.

\section{College Search}

Students receiving free computers may have been more likely to search for information about colleges because of the increased time, flexibility, and autonomy of use offered by having a home computer. Finding more information about 4-year college choices, requirements, financial aid, and what courses are transferable may represent one of the main reasons computer recipients are more likely to take transferable courses. It also might explain why treatment students have a higher level of actual transfers (although we note again the lack of statistical significance). On the follow-up survey, we asked students what they used computers for in the past month. ${ }^{23}$ In particular, we asked them whether they searched for information about college choices. We found that the treatment group was nearly 10 percentage points more likely to report searching for college information than the control group in spring/summer 2008. Among the treatment group,

\footnotetext{
${ }^{22}$ We also examine treatment heterogeneity by race and gender. Jepsen (2008) finds differences in 2-year and 4-year college completion rates by race and gender. We find no evidence of different effects by race or gender.

${ }^{23}$ We conducted a follow-up survey of study participants (treatment and control) in late spring/summer 2008 with a response rate of 65 percent. The baseline characteristics of the respondent sample look roughly similar to those of the full sample (see Fairlie and London 2012). The response rate was 61 percent for the control group and 69 percent for the treatment group. The difference is not statistically significant.
} 
43.3 percent of students reported searching for college information in the past month compared with 34.1 percent of the control group. The difference, however, is not statistically significant at conventional levels.

From a regression analysis reported in Table 9, we find that the treatment effect estimate is not sensitive to the inclusion of controls. We find that the treatment group has a 10.9 percentage point higher likelihood of searching for college information than the control group. Although the difference is not significant at conventional levels for a two-tailed test (the p-value is 0.126 for a two-tailed test), the point estimate suggests a potentially large effect. The point estimates imply an effect of 9.2 to 10.9 percentage points. These point estimates imply large effects relative to the average probability of searching for college information among the control group of 34.1 percent, but the confidence intervals are also large. The confidence interval for the treatment effect estimates including controls is [-0.030 to 0.248]. Power calculations indicate that slightly larger sample sizes would be needed to detect a statistically significant treatment effect given the control group mean of 0.34 and an effect size of 10 percentage points. The detection of smaller treatment effects, however, would require much larger sample sizes.

These findings are consistent with previous qualitative research indicating the importance of computers and the Internet for acquiring college information (Venegas 2007, Jones 2009, Owens 2007). Venegas (2007) finds that the Internet is used extensively by students in the search and application process for college and financial aid. She finds that low-income students in her study were at a major disadvantage in applying to colleges and for financial aid because of their lack of access to computers at school and home. In her study of African-American students, Jones (2009) finds that middle-class families have better access to computers at home than working-class families, and take advantage of this access to search more for college information. There is also direct evidence on the extensive use of technology among community college students, especially with colleges' online systems, to help in the transfer process to 4-year colleges (Owens 2007). In contrast, there is some evidence of the varying, "haphazard," or 
"accidental" quality of transfer counseling at community colleges (Dowd 2006), and criticism of transfer advising because of the use of part-time faculty and large caseloads (Council on Postsecondary Education 2004).

The increased flexibility, time and autonomy offered by having access to a home computer may enable low-income community college students to expand their ability to search for information about 4-year colleges. ${ }^{24}$ Although home computers also improve the ability to search for information about 2-year degrees and certificates, the relative effect may be much lower because these students are already enrolled in a community college where non-electronic information is readily available on campus. Improving college search might be an important mechanism for the causal relationship between home computers and taking transferable courses, although there is also the possibility that it reflects another measure of desire to transfer.

\section{Conclusions}

Rapidly rising tuition costs and recent calls to expand 2-year college enrollments suggest that community colleges will provide an increasingly important transfer function to 4-year colleges. Community colleges in some states, such as California, already play a major role in university education with nearly half of all 4-year college students having previously attended a community college (California Community Colleges Chancellor’s Office 2009). In this paper, we use data from the first-ever randomized field experiment providing free computers to students for home use to explore whether having access to home computers improves the transfer function of community colleges. If limited information is an important constraint for transferring to 4-year colleges, especially among low-income community college students, then having access to computers at home may help overcome this barrier and lead to higher labor market returns.

\footnotetext{
${ }^{24}$ Having access to a home computer may be especially useful for finding financial aid and scholarship information (Grazzi and Vergara 2009).
} 
The results from the field experiment indicate that the treatment group of students receiving free computers to use at home has a 4.8 percentage point higher probability of taking transferable courses than the control group of students not receiving free computers. Of courses taken by the treatment group, 66 percent are transferable to CSU or UC campuses compared with 61 percent of courses taken by the control group. Controlling for baseline characteristics does not change the conclusion - the treatment group of students receiving free computers has a 4.5 percentage point higher likelihood of taking transferable courses. LATE estimates of the effects of having a home computer on taking transferable courses range from 4.9 to 6.3 percentage points.

The results are less clear for the effects of home computers on actual transfers to 4-year colleges. We find positive point estimates for the treatment effect on actual transfers, but the estimates are not statistically significant. The confidence intervals for these estimates are wide and only rule out very large negative and large positive effects. Power calculations also reveal that large, prohibitively expensive sample sizes would be needed to obtain statistical significance unless the point estimates were larger.

Although the sample sizes would have to be considerably larger to reach statistical significance, the point estimates provide some suggestive evidence that the effects of home computers might be smaller on actual transfer rates than the effects on taking transferable courses. Home computers may have changed the desire to transfer or increased student confidence in taking more challenging and demanding transfer courses, but other barriers to transferring to 4-year colleges were just too large. Barriers such as the cost of 4-year colleges, added challenge of taking 4-year college courses, and lack of courses offered to accommodate nontraditional or working students might be especially restrictive (Council on Postsecondary Education 2004). We find some evidence that students who did not initially have a goal of transferring to a 4-year college had larger positive effects from the computers than undecided and transfer goal students. We also find some suggestive evidence that students with transfer goals 
benefit more from home computers in terms of increasing their likelihood of transferring to 4year colleges.

We also find suggestive evidence that college search increases from receiving home computers. Point estimates indicate that the treatment group has a roughly 10 percentage point higher probability of using a computer to search for college information than the control group (although again confidence intervals are large). The expanded ability of low-income community college students to find information about 4-year colleges may represent one of the mechanisms by which home computers increase transferable course taking.

Although there is concern that information constraints may limit interest in and the likelihood of transferring to 4-year colleges among low-income community college students, there is little direct evidence on the question. The findings from this experiment suggest that having access to a home computer may be useful for finding information about 4-year university choices, admission requirements, tuition, financial aid, and which courses are transferable, which ultimately may counteract some of the "diversion" effects of attending a community college. The 1.2 million community college students in the United States without access to home computers and the Internet, however, may be at a disadvantage in acquiring information helpful for transferring to 4-year universities and obtaining jobs requiring these skills. To overcome this barrier, policies that provide access to computers for low-income students, such as tax breaks or special loans for educational computer purchases, expanded computer refurbishing programs, and laptop check out programs may be needed (Servon 2002, Warschauer 2006). Addressing this barrier may become increasingly important as more application, financial-aid, registration and course information is being placed online and public institutions reduce staff in response to budget cutbacks. More research on these important questions, preferably with larger sample sizes, is clearly needed. 


\section{References}

Alfonso, Mariana. 2006. "The Impact of Community College Attendance on Baccalaureate Attainment,” Research in Higher Education, Vol. 47, No. 8 , 873-903.

American Association of Community Colleges and American Association of State Colleges and Universities. 2004. "Improving Access to the Baccalaureate," Washington, DC: Community College Press.

Attewell, Paul, and Juan Battle. 1999. "Home Computers and School Performance," The Information Society, 15: 1-10.

Fairlie, Robert W., Daniel O. Beltran, and Kuntal K. Das. 2010. "Home Computers and Educational Outcomes: Evidence from the NLSY97 and CPS," Economic Inquiry, 48(3): 771792.

California Colleges.edu. 2012. "The Official Source for College and Career Planning in California. 2012" http://www.californiacolleges.edu/finance/how-much-does-college-cost.asp

California Community Colleges Chancellor's Office. 2012. "http://www.cccco.edu/

California Community Colleges Chancellor's Office. 2009. “Accountability Reporting for the California Community Colleges,” A Report to the Legislature, Pursuant to AB 1417 (Pacheco, Stat. 2004, Ch. 581).

California Community Colleges Chancellor's Office. 2011. "Impact of Budget Cuts on the California Community Colleges \& Value of the System to California. http://californiacommunitycolleges.cccco.edu/policyinaction/keyfacts.aspx

California Teachers Association. 2012. "How Will You Pay For College?” http://ctainvest.org/home/saving-and-spending/saving-for-college/how-will-you-pay-forcollege.aspx

Council on Postsecondary Education, 2004. "Identifying Barriers to College Student Transfer: Key Findings from the 2004 Community and Technical College Student Survey and Focus Group Results,” http://cpe.ky.gov/NR/rdonlyres/05C9F848-5789-429D-BBE9933338B7E802/0/TransferStudySummarySCOPE.pdf

Dowd, Alicia C., and Glenn Gabbard. 2006. "The Study of Economic, Informational, and Cultural Barriers to Community College Student Transfer Access at Selective Institutions," The New England Resource Center for Higher Education at the University of Massachusetts Boston and the Center for Urban Education and the Tomás Rivera Policy Institute at the University of Southern California.

Fairlie, Robert W. 2004. "Race and the Digital Divide," Contributions to Economic Analysis \& Policy, The Berkeley Electronic Journals 3(1), Article 15: 1-38.

Fairlie, Robert W. 2005. "The Effects of Home Computers on School Enrollment," Economics of Education Review, 24(5): 533-547. 
Fairlie, Robert W., and Rebecca A. London. 2012. "The Effects of Home Computers on Educational Outcomes: Evidence from a Field Experiment with Community College Students," Economic Journal, 122(561): 727-753.

Fairlie, Robert W., and Jonathan Robinson. 2013. "Experimental Evidence on the Effects of Home Computers on Academic Achievement among Schoolchildren." American Economic Journal: Applied Economics 5(3): 211-240.

Fiorini, M. 2010. “The Effect of Home Computer Use on Children's Cognitive and NonCognitive Skills.” Economics of Education Review, 29: 55-72.

Fuchs, Thomas, and Ludger Woessmann. 2004. "Computers and Student Learning: Bivariate and Multivariate Evidence on the Availability and Use of Computers at Home and at School," CESIFO Working Paper No. 1321.

Furchtgott-Roth, Diana , Louis Jacobson, and Christine Mokher. 2009. Strengthening Community Colleges’ Influence On Economic Mobility, Economic Mobility Project, http://www.economicmobility.org/assets/pdfs/PEW_EMP_COMMUNITY_COLLEGES.pdf

Goldfarb, Avi, and Jeffrey Prince. 2008. "Internet Adoption and Usage Patterns are Different: Implications for the Digital Divide," Information Economics and Policy, 20(1), 2-15, March.

Gonzalez, Arturo, and Michael J. Hilmer 2006. "The Role of Two-Year Colleges in the Improving Situation of Hispanic Postsecondary Education,” Economics of Education Review 25(3): 249-257.

Grazzi, Matteo, and Sebasti Vergara. 2009. "ICT Access in Latin America: Evidence from Household Level," Economic Commission for Latin America and the Caribbean (ECLAC), United Nations Working Paper.

Grazzi, Matteo, and Sebasti Vergara. 2009. " Understanding the ICT Impacts at Household Level in Latin America," Economic Commission for Latin America and the Caribbean (ECLAC), United Nations Working Paper.

Hilmer, Michael J. 1997. "Does Community College Attendance Provide a Strategic Path to a Higher Quality Education?” Economics of Education Review, 17(1), 59-68.

Hoffman, Donna L. and Thomas P. Novak. 1998. "Bridging the Racial Divide on the Internet." Science 17 April: 390-391.

Jepsen, Christopher. 2008. "Multinomial probit estimates of college completion at 2-year and 4-year schools," Economics Letters, 98: 155-160.

Jepsen, Christopher, Kenneth Troske, and Paul Coomes. 2009. "The Labor-Market Returns to Community College Degrees, Diplomas, and Certificates," University College Dublin, Department of Economics working paper.

Jones, Steve. 2002. "The Internet Goes to College: How students are living in the future with today's technology,” Pew Internet Report. 
Karpinski, A.C. 2009. “A description of Facebook use and academic performance among undergraduate and graduate students,” paper presented at the Annual Meeting of the American Educational Research Association, San Diego, Calif.

Leigh, Duane E., and Andrew M. Gill. 2003. "Do Community Colleges really Divert Students from Earning Bachelor's Degrees?" Economics of Education Review 22 , 23-30.

Leigh, Duane E., and Andrew M. Gill. 2004. Evaluating Academic Programs in California's Community Colleges, San Francisco, CA: Public Policy Institute of California.

Leigh, Duane E., and Andrew M. Gill. 2007. Do Community Colleges Respond to Local Needs? Evidence from California, W.E. Kalamazoo, Michigan: Upjohn Institute for Employment Research.

Lenhart, Amanda, Joseph Kahne, Ellen Middaugh, Alexandra Rankin Macgill, Chris Evans, and Jessica Vitak. 2008. "Teens, Video Games, and Civics: Teens' gaming experiences are diverse and include significant social interaction and civic engagement," Pew Internet and American Life Project.

Lenhart, Amanda. 2009. "The Democratization of Online Social Networks: A look at the change in demographics of social network users over time," Pew Internet \& American Life Project, Presentation at AoIR 10.0, October 8, 2009.

Lewis, Randall A., and David H. Reiley. 2011. "Does Retail Advertising Work? Measuring the Effects of Advertising on Sales via a Controlled Experiment on Yahoo!" Yahoo! Research Working Paper.

Long, Bridget Terry, and Michael Kurlaender. 2009. "Do Community Colleges Provide a Viable Pathway to a Baccalaureate Degree?" Educational Evaluation and Policy Analysis, Vol. 31, No. 1, 30-53.

Malamud, Ofer, and Cristian Pop-Eleches. 2010. " Home Computer Use and the Development of Human Capital," Quarterly Journal of Economics, 126: 987-1027.

Mossberger, K., C. Tolbert, and M. Gilbert. 2006. "Race, Place, and Information Technology," Urban Affairs Review, 41(5): 583-620.

Mossberger, K., C. Tolbert, and M. Stansbury. 2003. Virtual Inequality: Beyond the Digital Divide. Georgetown University Press, Washington, DC.

Ono, Hiroshi, and Madeline Zavodny, 2003. "Race, Internet Usage, and E-Commerce," Review of Black Political Economy, 30, Winter: 7-22.

Owens, Karen R. 2007. Community College Transfer Students' Experiences of the Adjustment Process.

Pasek, Josh, and Eszter Hargittai. 2009. "Facebook and academic performance: Reconciling a media sensation with data," First Monday, Volume 14, Number 5 - 4.

Rouse, C. E. 1995. "Democratization or Diversion? The Effect of Community Colleges on Educational Attainment,” Journal of Business \& Economic Statistics, Vol. 13, No. 2 , 217-224. 
Rouse, Cecilia Elena. 1998. "Do Two-year Colleges Increase Overall Educational Attainment? Evidence from the States," Journal of Policy Analysis and Management. Fall, 17:4, pp. 595-620.

Sengupta, Ria, and Christopher Jepsen. 2006. "California’s Community College Students," California Counts: Population Trends and Profiles, Volume 8, Number 2, Public Policy Institute of California, November 2006.

Servon, Lisa J. 2002. Bridging the Digital Divide Technology, Community, and Public Policy. Malden: Blackwell Publishers Ltd.

Servon, Lisa J., and Robert Kaestner. 2008. "Consumer Financial Literacy and the Impact of Online Banking on the Financial Behavior of Lower-Income Bank Customers," The Journal of Consumer Affairs, 42(2): 271-305.

Schmitt, John, and Jonathan Wadsworth. 2006. "Is There an Impact of Household Computer Ownership on Children's Educational Attainment in Britain?” Economics of Education Review, 25: 659-673.

U.S. Census Bureau. 2011. Table A-3. Mean Earnings of Workers 18 Years and Over, by Educational Attainment, Race, Hispanic Origin, and Sex: 1975 to 2011, Educational Attainment, http://www.census.gov/hhes/socdemo/education/data/cps/historical/index.html

U.S. Department of Commerce. 2004. A Nation Online: Entering the Broadband Age. Washington, D.C.: U.S.G.P.O.

U.S. Department of Commerce. 2008. Networked Nation: Broadband in America 2007. National Telecommunications and Information Administration, U. S. Department of Commerce: Washington, D.C.

U.S. Department of Education, National Center for Education Statistics. 2011. Digest of Education Statistics, 2010.

U.S. White House. 2009. Education Plan. http://www.whitehouse.gov/issues/education.

University of California Office of the President. 2009. Master Plan For Higher Education In California, http://www.ucop.edu/acadinit/mastplan/mp.htm

Venegas, Kristan M. 2007. "The Internet and College Access: Challenges for Low Income Students,” American Academic-Volume Three, 141-154.

Vigdor, Jacob L., and Helen F. Ladd. 2010. "Scaling the Digital Divide: Home Computer Technology and Student Achievement,” National Bureau of Economic Research Working Paper No. 16078.

Warschauer, Mark. 2003. Technology and Social Inclusion: Rethinking the Digital Divide, MIT Press: Cambridge.

Warschauer, Mark. 2006. Laptops and Literacy: Learning in the Wireless Classroom, Teachers College Press. 
Zavodny, Madeline. 2006. "Does Watching Television Rot Your Mind? Estimates of the Effect on Test Scores,” Economics of Education Review, 25 (October 2006): 565-573. 
Appendix Table 1

Number of Transferable Courses for CSU and UC Campuses by Department

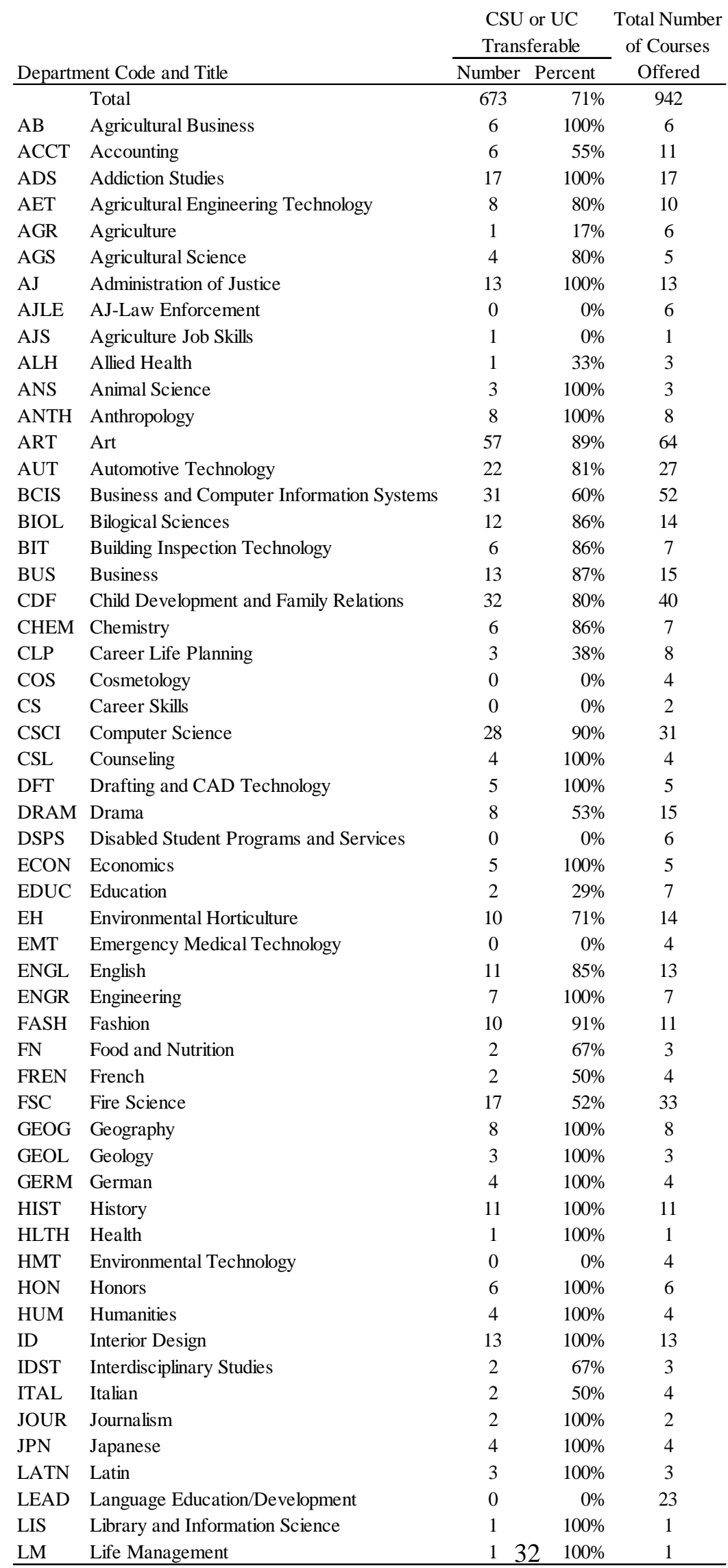


Appendix Table 1 (continued)

\begin{tabular}{|c|c|c|c|c|}
\hline & & $\begin{array}{c}\text { CSU } \\
\text { Trans } \\
\end{array}$ & $\begin{array}{l}\text { or UC } \\
\text { ferable }\end{array}$ & $\begin{array}{c}\text { Total Number } \\
\text { of Courses }\end{array}$ \\
\hline Departm & ent Code and Title & Number & Percent & Offered \\
\hline MATH & Mathematics & 14 & $64 \%$ & 22 \\
\hline MCS & Multicultural Studies & 2 & $100 \%$ & 2 \\
\hline MS & Machine Shop & 1 & $33 \%$ & 3 \\
\hline MSP & Multimedia Studies Program & 7 & $64 \%$ & 11 \\
\hline MUS & Music & 13 & $100 \%$ & 13 \\
\hline NR & Natural Resources & 8 & $100 \%$ & 8 \\
\hline NSG & Nursing & 32 & $97 \%$ & 33 \\
\hline $\mathrm{PE}$ & Physical Education & 47 & $43 \%$ & 110 \\
\hline PHIL & Philosophy & 8 & $100 \%$ & 8 \\
\hline PHO & Photography & 13 & $93 \%$ & 14 \\
\hline PHYS & Physics & 9 & $100 \%$ & 9 \\
\hline PLS & Plant Science & 4 & $100 \%$ & 4 \\
\hline POS & Political Science & 6 & $100 \%$ & 6 \\
\hline PSC & Physical Science & 7 & $100 \%$ & 7 \\
\hline PSY & Psychology & 12 & $100 \%$ & 12 \\
\hline READ & Reading & 1 & $33 \%$ & 3 \\
\hline REC & Recreation & 1 & $100 \%$ & 1 \\
\hline RLS & Real Estate & 7 & $100 \%$ & 7 \\
\hline $\mathrm{RT}$ & Respiratory Therapy & 0 & $0 \%$ & 13 \\
\hline RTVF & Radio, Television, and Film & 9 & $100 \%$ & 9 \\
\hline SBM & Small Business Management & 0 & $0 \%$ & 3 \\
\hline SOC & Sociology & 9 & $90 \%$ & 10 \\
\hline SPAN & Spanish & 5 & $71 \%$ & 7 \\
\hline $\mathrm{SPCH}$ & Speech Communication & 4 & $80 \%$ & 5 \\
\hline SPE & Special Education & 0 & $0 \%$ & 4 \\
\hline TOUR & Tourism and Travel & 13 & $93 \%$ & 14 \\
\hline WKE & Work Experience & 0 & $0 \%$ & 1 \\
\hline WLD & Welding & 15 & $88 \%$ & 17 \\
\hline
\end{tabular}

Notes: (1) Based on administrative data from Butte College. 
Appendix Table 2: Power Calculations for Experiment

Control Group Sample Proportion $=0.20$

Treatment- N Needed Confidence Interval Confidence Interval

Control for Statistal N=286 N=5000

\begin{tabular}{crrrrr} 
Difference & Significance & Lower & Upper & \multicolumn{1}{l}{ Lower } & Upper \\
\hline 0.00 & & -0.093 & 0.093 & -0.022 & 0.022 \\
0.01 & 25583 & -0.084 & 0.104 & -0.012 & 0.032 \\
0.02 & 6510 & -0.074 & 0.114 & -0.003 & 0.043 \\
0.05 & 1094 & -0.047 & 0.147 & 0.027 & 0.073 \\
0.10 & 294 & 0.000 & 0.200 & 0.076 & 0.124 \\
0.20 & 82 & 0.096 & 0.304 & 0.175 & 0.225 \\
\hline
\end{tabular}

Notes: (1) All power calculations are for proportion outcomes, and assume 0.05 level of significance, 0.8 power, and no continuity correction. (2) In STATA use sampsi and SAS use proc power. 
Figure 1

Home Computer with Internet Access Rates for Enrollees in Community College

Current Population Survey, October 2007 Microdata

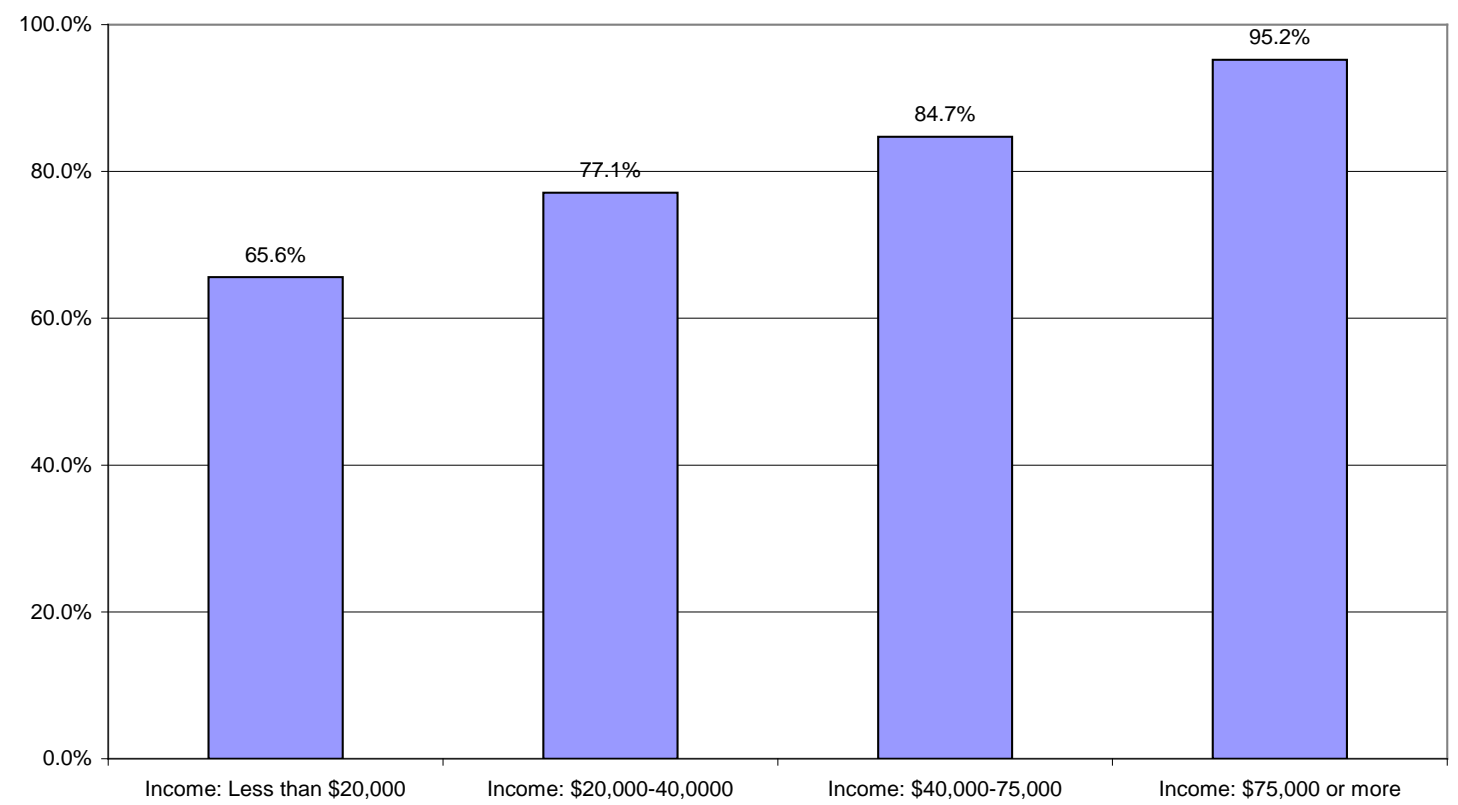


Figure 2

Total Number of California Community College Students Transferring to 4-Year Colleges

California Community Colleges Chancellor's Office (2002-2008)

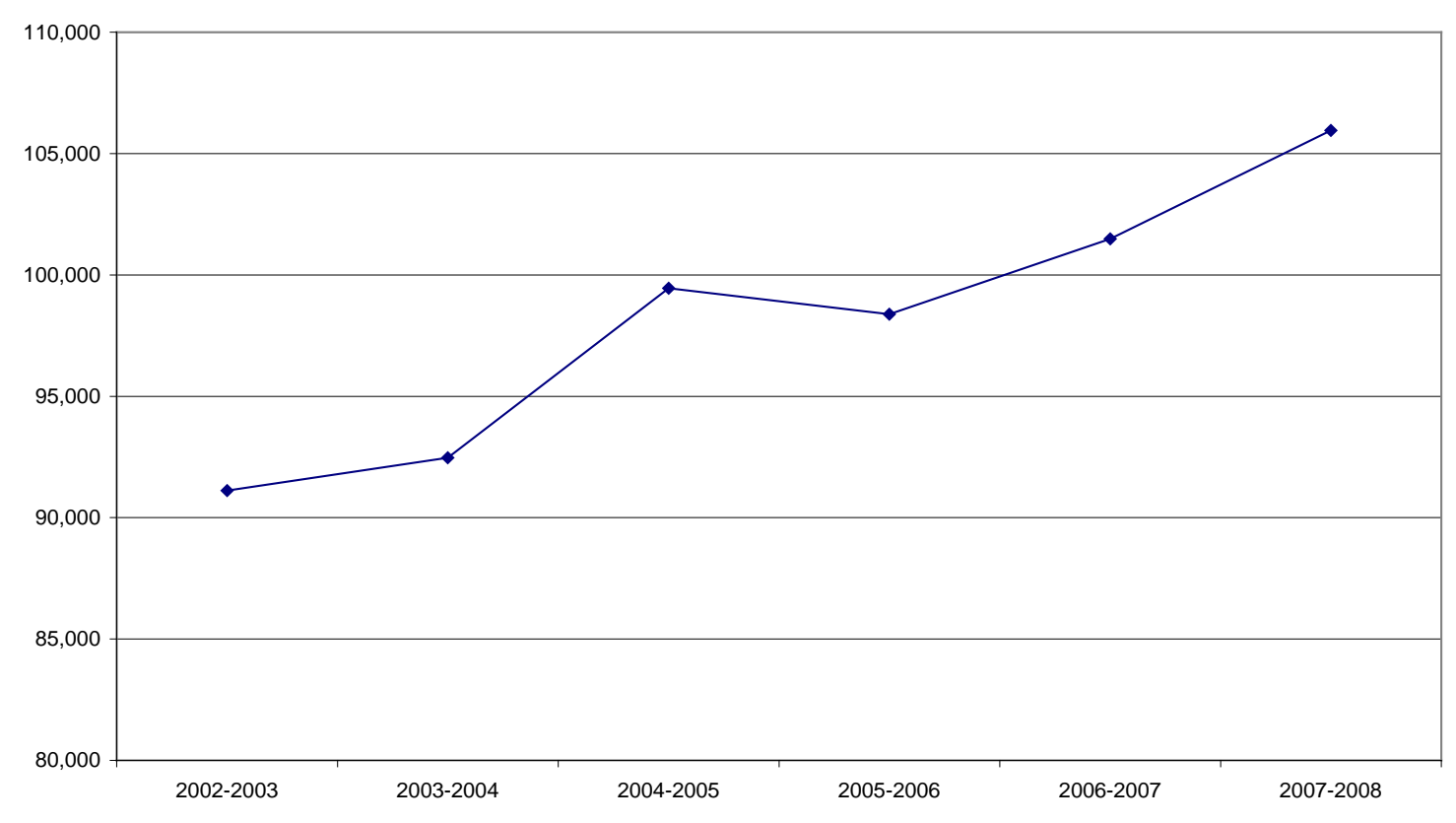


Table 1

Application Information for Study Participants, Financial Aid Students, and All Students

\begin{tabular}{lrrr} 
& $\begin{array}{c}\text { Study } \\
\text { Participants }\end{array}$ & $\begin{array}{c}\text { All Financial Aid } \\
\text { Students }\end{array}$ & $\begin{array}{c}\text { All Entering } \\
\text { Students }\end{array}$ \\
\hline Gender & & & \\
Female & $62.6 \%$ & $54.7 \%$ & $55.2 \%$ \\
Male & $35.7 \%$ & $43.6 \%$ & $43.6 \%$ \\
$\quad$ Missing & $1.7 \%$ & $1.7 \%$ & $1.2 \%$ \\
Race/Ethnicity & & & \\
White & $60.1 \%$ & $61.3 \%$ & $65.2 \%$ \\
Asian and Pacific Islander & $8.0 \%$ & $8.2 \%$ & $7.0 \%$ \\
African-American & $3.1 \%$ & $3.2 \%$ & $2.6 \%$ \\
Latino & $16.8 \%$ & $15.6 \%$ & $13.1 \%$ \\
Native American & $2.1 \%$ & $2.9 \%$ & $2.2 \%$ \\
Other & $1.0 \%$ & $1.2 \%$ & $1.2 \%$ \\
$\quad$ Unknown & $8.7 \%$ & $7.6 \%$ & $8.7 \%$ \\
English language & & & \\
$\quad$ English & $81.8 \%$ & $83.7 \%$ & $80.1 \%$ \\
Not English & $7.0 \%$ & $6.7 \%$ & $7.8 \%$ \\
Unknown/Uncollected & $11.2 \%$ & $9.6 \%$ & $12.1 \%$ \\
& & & \\
Sample size & 286 & 1,042 & 6,681 \\
\hline
\end{tabular}

Note: Based on administrative data provided by Butte College for entering students in Fall 2006. 
Table 2

Background Characteristics of Study Participants from Baseline Survey

\begin{tabular}{|c|c|c|c|c|}
\hline & $\begin{array}{c}\text { All Study } \\
\text { Participants }\end{array}$ & $\begin{array}{c}\text { Treatment } \\
\text { Group }\end{array}$ & $\begin{array}{l}\text { Control } \\
\text { Group }\end{array}$ & $\begin{array}{c}\text { P-Value for } \\
\text { Treatment/ } \\
\text { Control } \\
\text { Difference }\end{array}$ \\
\hline Female & $63.3 \%$ & $64.5 \%$ & $62.1 \%$ & 0.666 \\
\hline Latino & $17.8 \%$ & $15.6 \%$ & $20.0 \%$ & 0.333 \\
\hline Other Minority & $18.2 \%$ & $21.3 \%$ & $15.2 \%$ & 0.182 \\
\hline Age & 25.0 & 24.9 & 25.0 & 0.894 \\
\hline Parent some college & $37.8 \%$ & $41.8 \%$ & $33.8 \%$ & 0.161 \\
\hline Parent college graduate & $22.0 \%$ & $18.4 \%$ & $25.5 \%$ & 0.150 \\
\hline High school grades As and Bs & $30.4 \%$ & $32.6 \%$ & $28.3 \%$ & 0.426 \\
\hline High school grades Bs and Cs & $56.6 \%$ & $55.3 \%$ & $57.9 \%$ & 0.657 \\
\hline Live with own children & $27.3 \%$ & $27.7 \%$ & $26.9 \%$ & 0.885 \\
\hline Live with parents & $34.6 \%$ & $31.2 \%$ & $37.9 \%$ & 0.234 \\
\hline Household income: $\$ 10,000$ - 19,999 & $31.5 \%$ & $30.5 \%$ & $32.4 \%$ & 0.728 \\
\hline Household income: $\$ 20,000$ - 39,999 & $25.9 \%$ & $27.7 \%$ & $24.1 \%$ & 0.498 \\
\hline Household income: $\$ 40,000$ or more & $16.8 \%$ & $14.9 \%$ & $18.6 \%$ & 0.401 \\
\hline Sample size & 286 & 141 & 145 & \\
\hline
\end{tabular}

Note: Based on baseline survey administered to all study participants. 
Table 3

Educational Goals at Time of Application

\begin{tabular}{|c|c|c|c|c|c|c|}
\hline & $\begin{array}{c}\text { Study } \\
\text { Participants }\end{array}$ & $\begin{array}{l}\text { Treatment } \\
\text { Group }\end{array}$ & $\begin{array}{l}\text { Control } \\
\text { Group }\end{array}$ & $\begin{array}{l}\text { P-Value for } \\
\text { Treat./Control } \\
\text { Difference }\end{array}$ & $\begin{array}{c}\text { All Financial } \\
\text { Aid } \\
\text { Students } \\
\end{array}$ & $\begin{array}{l}\text { All Butte } \\
\text { College } \\
\text { Students }\end{array}$ \\
\hline \multicolumn{7}{|c|}{ Educatonal goals at initial application } \\
\hline Transfer goal & $31.5 \%$ & $29.8 \%$ & $33.1 \%$ & 0.548 & $33.6 \%$ & $24.5 \%$ \\
\hline Non-transfer goal & $24.5 \%$ & $26.2 \%$ & $22.8 \%$ & 0.495 & $25.7 \%$ & $32.2 \%$ \\
\hline Undecided goal & $37.4 \%$ & $36.9 \%$ & $37.9 \%$ & 0.855 & $36.5 \%$ & $33.9 \%$ \\
\hline Unknown goal & $6.6 \%$ & $7.1 \%$ & $6.2 \%$ & 0.765 & $4.2 \%$ & $9.4 \%$ \\
\hline Sample size & 286 & 141 & 145 & & 1042 & 6681 \\
\hline
\end{tabular}

Notes: (1) Based on administrative data provided by Butte College for students at the time of application. (2) Non-transfer goals include obtaining degree or certificate without transfering, and discovering career interest, preparing for a new career, updating job skills, maintaining occupational certificates or licenses, intellectual or cultural development, improving basic skills in English, reading or math, and completing credits for a high school diploma or GED. 
Table 4

Transfer Course Regressions

\begin{tabular}{lcccc} 
& \multicolumn{2}{c}{ OLS Estimates } & \multicolumn{2}{c}{ IV Estimates } \\
& & & Lower Bound & Upper Bound \\
& $(1)$ & $(2)$ & $(3)$ & $(4)$ \\
\hline Treatment & 0.0479 & 0.0445 & 0.0494 & 0.0625 \\
& $(0.0239)$ & $(0.0226)$ & $(0.0251)$ & $(0.0318)$ \\
& & & & \\
Baseline controls & No & Yes & Yes & Yes \\
& & & & \\
Control group mean $(\mathrm{Y})$ & 0.6116 & 0.6116 & 0.6116 & 0.6116 \\
Sample Size & 2,658 & 2,658 & 2,658 & 2,658 \\
\hline
\end{tabular}

Notes: (1) The dependent variable is whether the course is transferable to a California State University or University of California campus. (2) Robust standard errors are reported and adjusted for multiple courses taken by study participants. (3) Baseline controls include gender, race/ethnicity, age, parents' highest education level, high school grades, presence of own children, live with parents, family income, and educational goals. (4) The dependent variable in the first-stage regression in the IV model is obtaining a new computer. The lower (upper) bound estimate assumes that all control group non-compliers obtained computers at the end (beginning) of the survey period. 
Table 5

Percent Transfer Course Regressions

\begin{tabular}{lcccc} 
& \multicolumn{2}{c}{ OLS Estimates } & \multicolumn{2}{c}{ IV Estimates } \\
& & & Lower Bound & Upper Bound \\
& $(1)$ & $(2)$ & $(3)$ & $(4)$ \\
\hline Treatment & 0.0542 & 0.0545 & 0.0598 & 0.0770 \\
& $(0.0280)$ & $(0.0291)$ & $(0.0318)$ & $(0.0410)$ \\
Baseline controls & No & Yes & Yes & Yes \\
Control group mean $(Y)$ & & & & \\
Sample Size & 0.6051 & 0.6051 & 0.6051 & 0.6051 \\
\hline
\end{tabular}

Notes: (1) The dependent variable is the percent of courses transferable to a California State University or University of California campus taken by each student. (2) Robust standard errors are reported. (3) Baseline controls include gender, race/ethnicity, age, parents' highest education level, high school grades, presence of own children, live with parents, family income, and educational goals. (4) The dependent variable in the firststage regression in the IV model is obtaining a new computer. The lower (upper) bound estimate assumes that all control group non-compliers obtained computers at the end (beginning) of the survey period. 
Table 6

4-Year College Transfer Regressions

\begin{tabular}{lcccc} 
& \multicolumn{2}{c}{ OLS Estimates } & \multicolumn{2}{c}{ IV Estimates } \\
& & & Lower Bound & Upper Bound \\
& $(1)$ & $(2)$ & $(3)$ & $(4)$ \\
\hline Treatment & 0.0128 & 0.0103 & 0.0113 & 0.0145 \\
& $(0.0485)$ & $(0.0464)$ & $(0.0508)$ & $(0.0655)$ \\
Baseline controls & No & Yes & Yes & Yes \\
& & & & \\
Control group mean $(\mathrm{Y})$ & 0.2000 & 0.2000 & 0.2000 & 0.2000 \\
Sample Size & 281 & 281 & 281 & 281 \\
\hline
\end{tabular}

Notes: (1) The dependent variable is whether the student transfers to a 4-year college. (2) Robust standard errors are reported. (3) Baseline controls include gender, race/ethnicity, age, parents' highest education level, high school grades, presence of own children, live with parents, family income, and educational goals. (4) The dependent variable in the first-stage regression in the IV model is obtaining a new computer. The lower (upper) bound estimate assumes that all control group non-compliers obtained computers at the end (beginning) of the survey period. 
Table 7

California State University Transfer Regressions

\begin{tabular}{lcccc} 
& \multicolumn{2}{c}{ OLS Estimates } & \multicolumn{2}{c}{ IV Estimates } \\
& $(1)$ & $(2)$ & Lower Bound & Upper Bound \\
& 0.0272 & 0.0274 & 0.0301 & $(4)$ \\
\hline Treatment & $(0.0465)$ & $(0.0446)$ & $(0.0488)$ & 0.0387 \\
& No & Yes & Yes & Yes \\
Baseline controls & & & & \\
& 0.1714 & 0.1714 & 0.1714 & 0.1714 \\
Control group mean $(\mathrm{Y})$ & 281 & 281 & 281 & 281 \\
Sample Size & 281
\end{tabular}

Notes: (1) The dependent variable is whether the student transfers to a California State University campus. (2) Robust standard errors are reported. (3) Baseline controls include gender, race/ethnicity, age, parents' highest education level, high school grades, presence of own children, live with parents, family income, and educational goals. (4) The dependent variable in the first-stage regression in the IV model is obtaining a new computer. The lower (upper) bound estimate assumes that all control group non-compliers obtained computers at the end (beginning) of the survey period. 
Table 8

Transfer Course and 4-Year College Transfer Regressions with Interactions for Educational Goals

\begin{tabular}{|c|c|c|c|c|}
\hline & \multicolumn{4}{|c|}{ OLS Estimates } \\
\hline & \multicolumn{2}{|c|}{ Transfer Course } & \multicolumn{2}{|c|}{ 4-Yr College Transfer } \\
\hline & $(1)$ & $(2)$ & (3) & $(4)$ \\
\hline \multirow[t]{2}{*}{ Treatment } & -0.0160 & 0.0592 & 0.0202 & -0.0242 \\
\hline & $(0.0384)$ & $(0.0360)$ & $(0.0776)$ & $(0.0610)$ \\
\hline \multirow[t]{2}{*}{ Treatment`transfer goal } & 0.0740 & & 0.0267 & \\
\hline & $(0.0572)$ & & $(0.1282)$ & \\
\hline \multirow{2}{*}{ Treatment*non-transfer goal } & 0.1341 & & -0.1412 & \\
\hline & $(0.0628)$ & & $(0.1078)$ & \\
\hline Treatment*above median percentage of transerable & & -0.0272 & & 0.0640 \\
\hline courses taken prior to treatment (fall 2006) & & $(0.0451)$ & & $(0.0957)$ \\
\hline Above median percentage of transferable courses & & 0.1092 & & 0.0452 \\
\hline taken prior to treatment (fall 2006) & & $(0.0334)$ & & $(0.0687)$ \\
\hline Baseline controls & Yes & Yes & Yes & Yes \\
\hline Mean of dependent variable & 0.6343 & 0.6343 & 0.2064 & 0.2064 \\
\hline Mean for "unknown" goal & 0.5812 & & 0.1667 & \\
\hline Mean for "transfer" goal & 0.6761 & & 0.3146 & \\
\hline Mean for "other" goal & 0.6088 & & 0.0882 & \\
\hline Sample Size & 2,658 & 2,658 & 281 & 281 \\
\hline
\end{tabular}

Notes: (1) The dependent variable is whether the course is transferable to a California State University or University of California campus in Specifications 1 and 2 and whether the student transfers to a 4-year college in Specifications 3 and 4. (2) Robust standard errors are reported and adjusted for multiple courses taken by study participants. (3) Baseline controls include gender, race/ethnicity, age, parents' highest education level, high school grades, presence of own children, live with parents, family income, and educational goals. 
Table 9

College Search Regressions

\begin{tabular}{|c|c|c|c|c|}
\hline & OLS E & imates & IV E & nates \\
\hline & & & Lower Bour & Jpper Bound \\
\hline & $(1)$ & (2) & (3) & $(4)$ \\
\hline Treatment & 0.0921 & 0.1090 & 0.1194 & 0.1539 \\
\hline & $(0.0717)$ & $(0.0709)$ & $(0.0777)$ & $(0.1001)$ \\
\hline Baseline controls & No & Yes & Yes & Yes \\
\hline Control group mean $(\mathrm{Y})$ & 0.3409 & 0.3409 & 0.3409 & 0.3409 \\
\hline Sample Size & 185 & 185 & 185 & 185 \\
\hline $\begin{array}{l}\text { Notes: (1) The dependen } \\
\text { information on colleges. } \\
\text { controls include gender, } \\
\text { school grades, presence } \\
\text { educational goals. (4) Th } \\
\text { model is obtaining a new } \\
\text { all control group non-con } \\
\text { survey period. }\end{array}$ & $\begin{array}{l}\text { is whethe } \\
\text { st standar } \\
\text { icity, age, } \\
\text { hildren, liv } \\
\text { dent variak } \\
\text { r. The lov } \\
\text { tained cor }\end{array}$ & $\begin{array}{l}\text { tudents us } \\
\text { rrors are } \\
\text { arents' higl } \\
\text { vith parent } \\
\text { in the first } \\
\text { (upper) b } \\
\text { uters at th }\end{array}$ & $\begin{array}{l}\text { ed computer } \\
\text { ported. (3) } \\
\text { est educatio } \\
\text { family inco } \\
\text { stage regres } \\
\text { und estimat } \\
\text { end (beginr }\end{array}$ & $\begin{array}{l}\text { search for } \\
\text { eline } \\
\text { vel, high } \\
\text { and } \\
\text { in the IV } \\
\text { sumes that } \\
\text { of the }\end{array}$ \\
\hline
\end{tabular}

